\title{
Environmental exposures during windows of susceptibility for breast cancer: a framework for prevention research
}

Mary Beth Terry ${ }^{1 \dagger}$, Karin B. Michels ${ }^{2 \dagger}$, Julia Green Brody ${ }^{3}$, Celia Byrne ${ }^{4}$, Shiuan Chen ${ }^{5}$, D. Joseph Jerry ${ }^{6}$, Kristen M. C. Malecki ${ }^{7}$, Mary Beth Martin ${ }^{8}$, Rachel L. Miller ${ }^{9}$, Susan L. Neuhausen ${ }^{10}$, Kami Silk ${ }^{11}$, Amy Trentham-Dietz ${ }^{12^{*}}$ (D) and on behalf of Breast Cancer and the Environment Research Program (BCERP)

\begin{abstract}
Background: The long time from exposure to potentially harmful chemicals until breast cancer occurrence poses challenges for designing etiologic studies and for implementing successful prevention programs. Growing evidence from animal and human studies indicates that distinct time periods of heightened susceptibility to endocrine disruptors exist throughout the life course. The influence of environmental chemicals on breast cancer risk may be greater during several windows of susceptibility (WOS) in a woman's life, including prenatal development, puberty, pregnancy, and the menopausal transition. These time windows are considered as specific periods of susceptibility for breast cancer because significant structural and functional changes occur in the mammary gland, as well as alterations in the mammary micro-environment and hormone signaling that may influence risk. Breast cancer research focused on these breast cancer WOS will accelerate understanding of disease etiology and prevention.

Main text: Despite the plausible heightened mechanistic influences of environmental chemicals on breast cancer risk during time periods of change in the mammary gland's structure and function, most human studies of environmental chemicals are not focused on specific WOS. This article reviews studies conducted over the past few decades that have specifically addressed the effect of environmental chemicals and metals on breast cancer risk during at least one of these WOS. In addition to summarizing the broader evidence-base specific to WOS, we include discussion of the $\mathrm{NIH}$-funded Breast Cancer and the Environment Research Program (BCERP) which included population-based and basic science research focused on specific WOS to evaluate associations between breast cancer risk and particular classes of endocrine-disrupting chemicals-including polycyclic aromatic hydrocarbons, perfluorinated compounds, polybrominated diphenyl ethers, and phenols-and metals. We outline ways in which ongoing transdisciplinary BCERP projects incorporate animal research and human epidemiologic studies in close partnership with community organizations and communication scientists to identify research priorities and effectively translate evidence-based findings to the public and policy makers.
\end{abstract}

Conclusions: An integrative model of breast cancer research is needed to determine the impact and mechanisms of action of endocrine disruptors at different WOS. By focusing on environmental chemical exposure during specific WOS, scientists and their community partners may identify when prevention efforts are likely to be most effective.

Keywords: Breast neoplasms, Puberty, Pregnancy, Menopause, Environment

\footnotetext{
* Correspondence: trentham@wisc.edu

${ }^{\dagger}$ Mary Beth Terry and Karin B. Michels should be considered shared first authors.

${ }^{12}$ Department of Population Health Sciences and Carbone Cancer Center,

School of Medicine and Public Health, University of Wisconsin-Madison, 610

Walnut St., WARF Room 307, Madison, WI 53726, USA

Full list of author information is available at the end of the article
}

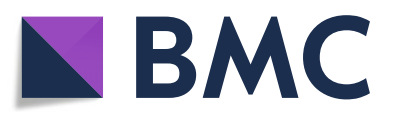

(c) The Author(s). 2019 Open Access This article is distributed under the terms of the Creative Commons Attribution 4.0 International License (http://creativecommons.org/licenses/by/4.0/), which permits unrestricted use, distribution, and reproduction in any medium, provided you give appropriate credit to the original author(s) and the source, provide a link to the Creative Commons license, and indicate if changes were made. The Creative Commons Public Domain Dedication waiver (http://creativecommons.org/publicdomain/zero/1.0/) applies to the data made available in this article, unless otherwise stated. 


\section{Background}

Despite the considerable personal and societal burden from breast cancer, primary prevention efforts encounter challenges. Unlike other cancers that are linked to a predominant risk factor (e.g., smoking and lung cancer [1], human papillomavirus, and cervical cancer [2]), most established breast cancer risk factors have modest associations; moreover, many risk factors are not conducive to population-level intervention. The American Cancer Society guidelines for breast cancer prevention include limiting alcohol intake, avoiding post-menopausal hormone use, increasing physical activity, and maintaining a healthy body weight [3]. Yet even considering these factors, estimates indicate that a substantial proportion of breast cancer risk remains unexplained $[4,5]$.

Migrant studies, atomic bomb survivor studies, and experimental model studies reinforce the concept that exposures during certain periods in a woman's life are important to later breast cancer risk [6-9]. These time intervals represent windows of susceptibility (WOS) and coincide with landmark events when a woman's breast tissue changes in structure and function including the prenatal, pubertal, pregnancy, and menopausal WOS. Epidemiologic data support that both medications [10] and medical conditions $[11,12]$ during these WOS may affect breast cancer risk; more limited evidence addresses specific environmental chemicals and metals during these same WOS. In 2003, the National Institute for Environmental Health Sciences (NIEHS) initiated the Breast Cancer and the Environment Research Program (BCERP) with support from the National Cancer Institute (NCI) to specifically examine whether environmental exposures during the pubertal WOS affect the timing of puberty, a risk factor for breast cancer. Since 2009, BCERP expanded the WOS to include the prenatal, pregnancy, and menopausal transition WOS. In addition, studies of mammographic breast density (MBD), breast tissue measurements, and other intermediate biomarkers of the effects of environmental exposures were included. The BCERP consortium unites basic and population scientists in advancing our understanding of the role of environmental chemicals during WOS in breast cancer risk. Scientific research in BCERP also builds from community partnerships and collaborations with communication scientists within the consortium to facilitate direct translation to the public (Fig. 1).

Numerous previous studies examined environmental chemical exposure and breast cancer risk; however, most research in humans has not specifically focused on measuring environmental chemical exposures during WOS (for review, see [13, 14]). For example, of the 146 epidemiologic reports published in 2006-2016 on environmental chemicals and incident breast cancer, only 16 (11\%) report on exposures measured during a specific WOS [14]. In this review, we outline the scientific evidence generated by experimental and epidemiologic scientists including (but not limited to) those in BCERP addressing the link between breast cancer risk and environmental chemicals and metals within four WOSprenatal, puberty, pregnancy, and the menopausal transition-to inform breast cancer etiology and future interventions.

\section{Windows of susceptibility (WOS)}

Breast cancer etiology appears to be driven in part by perturbations to breast tissue as well as alterations of the

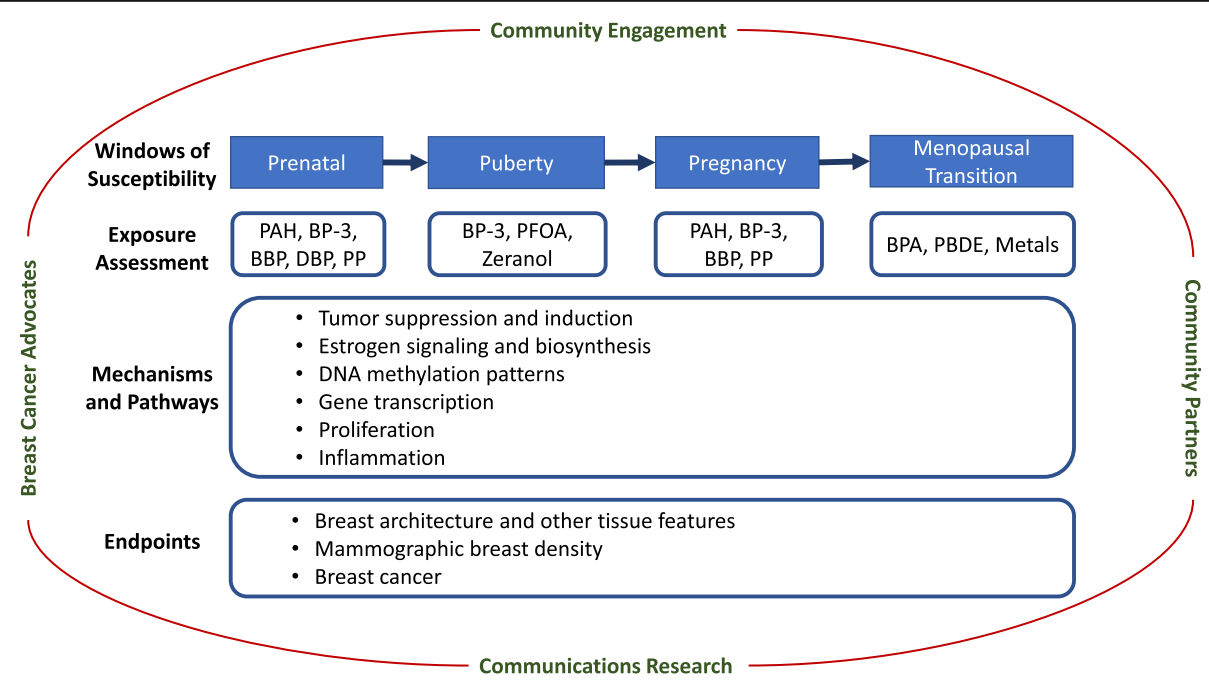

Fig. 1 BCERP framework. A model of transdisciplinary community-engaged research by epidemiologists, basic scientists, communication researchers, and advocates to examine environmental causes of breast cancer, as conducted by the Breast Cancer and the Environment Research Program (BCERP) 
mammary gland micro-environment during critical windows. Here we briefly summarize breast tissue changes occurring during each WOS, review evidence that addresses environmental carcinogenesis during each WOS, and outline the motivation for ongoing research on the chemicals and metals targeted in BCERP.

\section{Prenatal WOS}

The prenatal period is a particularly vulnerable WOS because breast tissue begins to develop in the embryonic stage when epidermal cells in concert with embryonic mesenchyme become breast buds [15-18]. Faster fetal growth and greater birth-weight increase breast cancer risk later in life [19-21]. Proposed mechanisms by which chemicals can alter normal mammary development trajectories $[15,18,19,22,23]$ include changes in maternal hormone levels regulating development and sex differentiation, high levels of growth factors, potential DNA damage and mutations in germ cells, and other genetic or epigenetic processes [24].

Pregnancy and birth cohorts reveal possible associations between environmental chemicals during the prenatal period and breast cancer. The Child Health and Development Studies (CHDS) found high levels of maternal exposure to dichlorodiphenyltrichloroethane (DDT) during pregnancy increased the daughters' later breast cancer risk to age 52 nearly fourfold compared to daughters of women with low levels of exposure (Table 1) [25]. Although production of many of the organochlorine chemicals-including dioxins, polychlorinated biphenyls (PCBs), and pesticides such as DDT-stopped in the 1970s, there is continued exposure to these complex mixtures with diverse biological activity. Animal fats and fish from contaminated waters are on-going sources of human exposure as a result of bioaccumulation [26]; PCB exposure also persists through inhalation both outdoors and of indoor air and dust from caulk, building materials, and floor finishes [27]. Organochlorines are hormonally active and may contribute to breast cancer by altering mammary gland development or hormone responsiveness early in life, or by promoting tumor growth [25]. Epidemiologic studies of DDT exposure measured outside of a WOS and breast cancer risk were less likely to report consistent findings $[14,19]$.

Another class of chemical exposures of concern during the prenatal WOS is polycyclic aromatic hydrocarbons (PAH). PAH are produced as a result of combustion of hydrocarbons. Some of the common sources of PAH exposure include consuming grilled meats and certain other food items [28], inhaling cigarette smoke and motor vehicle exhaust [29], and exposure to industrial processes [29-31]. PAH are widespread and enter the body largely through ingestion and inhalation of suspended particulate matter [32, 33]. The International
Agency for Research on Cancer classifies PAH as probable carcinogens; the US Environmental Protection Agency lists PAH as possible carcinogens [34, 35].

Like DDT and other organochlorines, PAH are lipophilic and stored in fat tissue including breast tissue [36]. Most PAH compounds are weakly estrogenic and may induce cell proliferation via activation of the estrogen receptor (ER) [37]. Exposure to PAH was linked to mammary cancer in rodents [38]. PAH exposure has been measured directly in both blood [39] and breast tissue [40], and higher levels of PAH-DNA adducts have been found in breast cancer cases compared with women without breast cancer [41]. Similarly, breast cancer cases reported higher levels of $\mathrm{PAH}$ exposures than controls based on questionnaire assessments of indirect exposure [42-46]. For all these epidemiologic studies, specific WOS were not investigated. Because experimental and epidemiologic associations implicate prenatal PAH exposure in multiple adverse health effects including obesity [47-49], one focus of BCERP is the impact of $\mathrm{PAH}$ exposure during the prenatal WOS. BCERP research specifically addresses how exposure to PAH during the prenatal and pregnancy WOS may increase the development of mammary tumors in mice. Concurrent human studies within BCERP evaluate how prenatal PAH exposure alters breast tissue development and tissue composition in adolescent girls.

\section{Pubertal window of susceptibility}

The female breast undergoes rapid changes and growth during puberty. The highest density of proliferating terminal end buds that mediate ductal elongation and establishment of the ductal tree and primitive lobular structures form during puberty [50, 51]. This time period is considered highly estrogen sensitive based on evidence in mice where pubertal growth is almost completely stunted in mice lacking $\mathrm{ER} \alpha[52,53]$. The profound hormonal changes, including a dramatic increase in endogenous estrogen biosynthesis by stimulating hormones from the hypothalamus and pituitary gland, culminate in the onset of menarche. Endocrinedisrupting chemicals (EDC) in the environment may affect the interaction of endogenous estrogens and progestogens with their receptors and together have carcinogenic impact. Exposure to EDC may reprogram normal stem cells which are subsequently transformed by additional estrogen exposures [54]. The number of mammary stem cells expands during this period of proliferation, and these cells distribute throughout the ductal tree [55]. Three previous BCERP puberty cohorts examined exposure to several environmental chemicals in relation to pubertal timing as endpoints and reported that higher levels of some (but not all) chemicals, including 


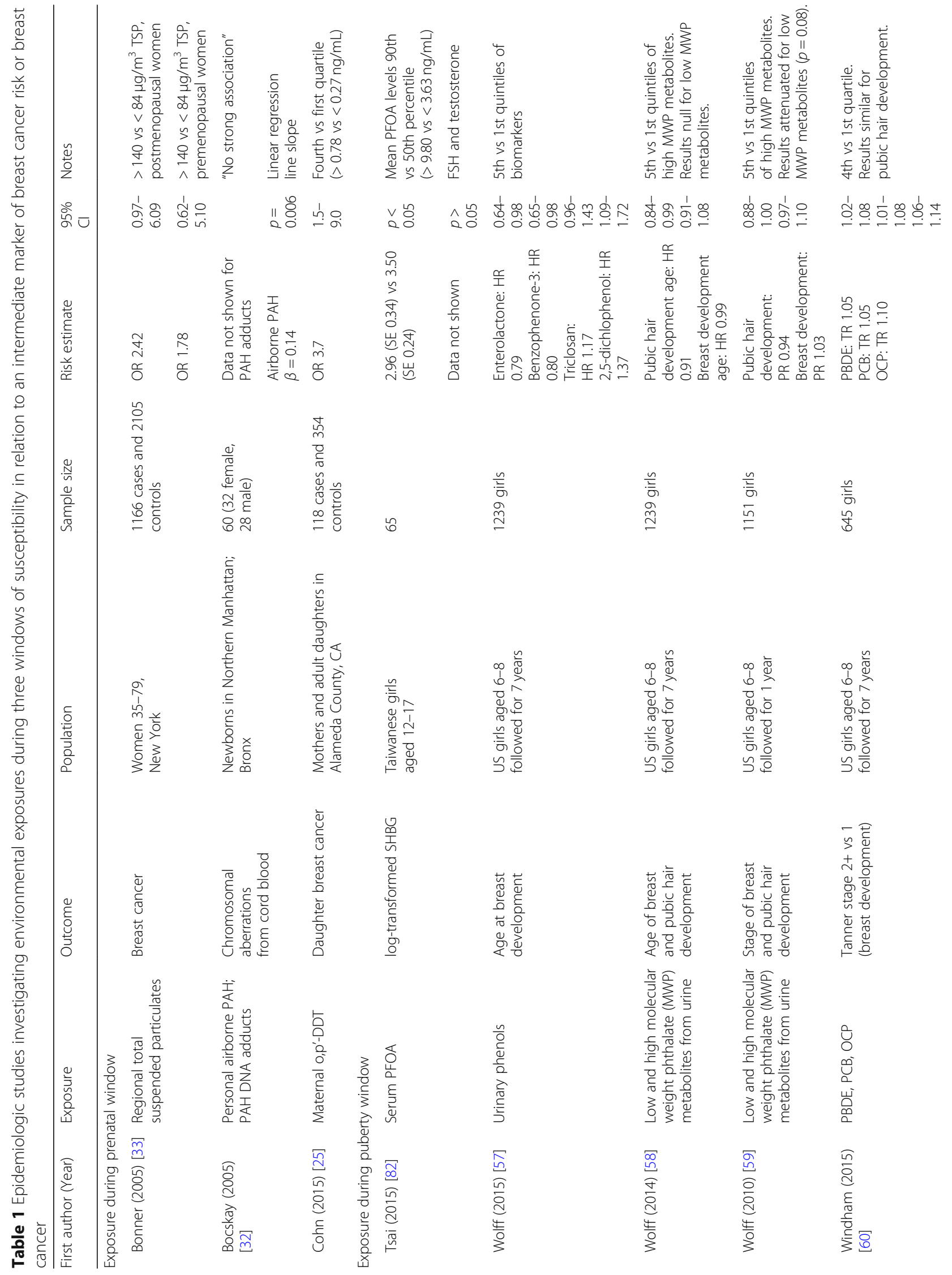




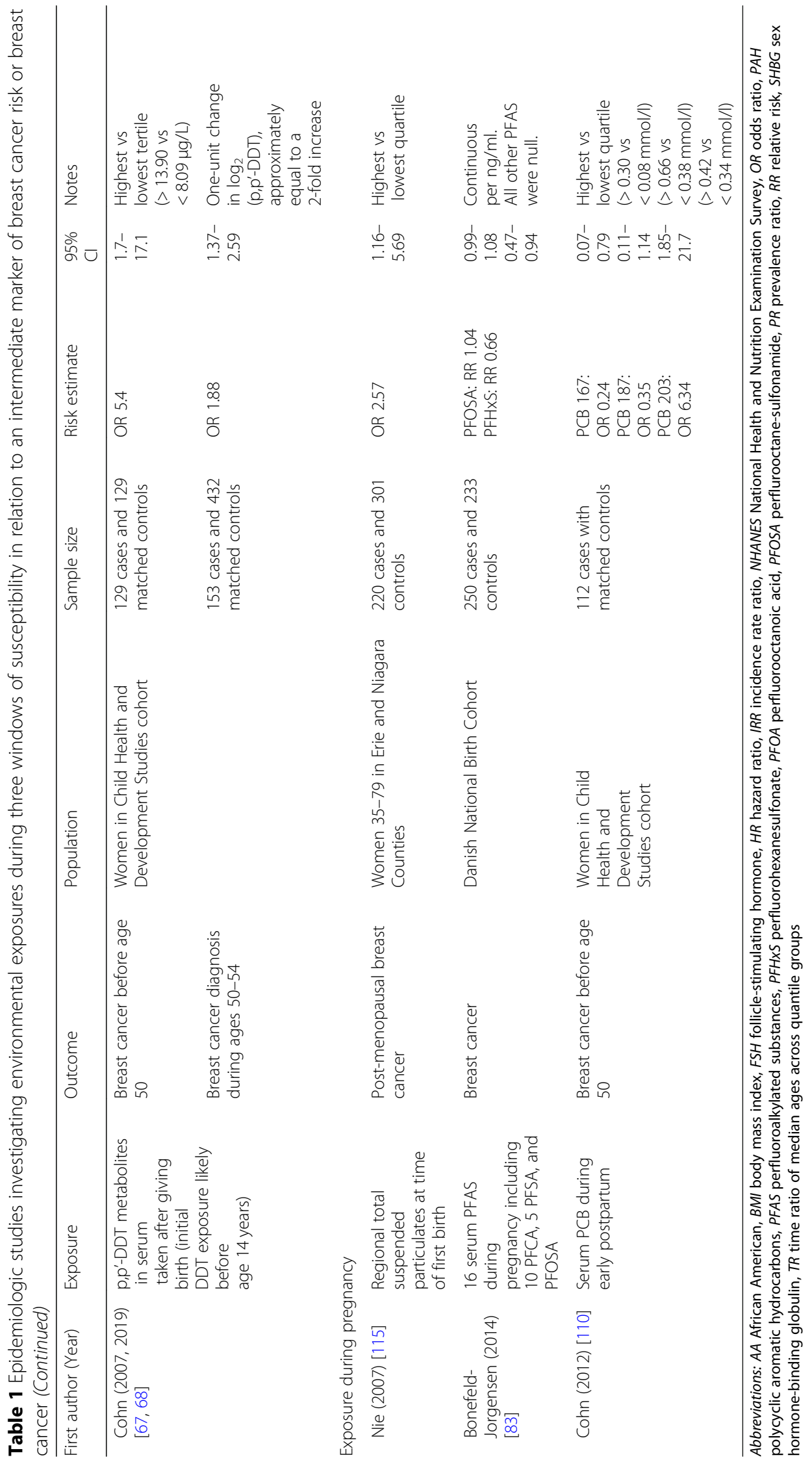


various phenols (including bisphenol A [BPA]), parabens, phthalates, and persistent organohalogenated compounds, were associated with delayed median puberty endpoints by 5-11 months when comparing extreme categories of exposure (Table 1) [56-60].

Epidemiologic and experimental evidence from investigators outside of BCERP suggest environmental exposures during the pubertal WOS are associated with an increase in breast cancer risk. Human studies have examined high doses of radiation from medical treatment or atomic bomb exposure [61, 62] and nutritional exposures during puberty and adolescence [63-66]. DDT exposure during infancy and puberty was associated with increased breast cancer risk $[67,68]$. In experimental studies of rats, exposure to a carcinogen (dimethylbenz [a] anthracene, DMBA) resulted in the highest number of tumors when administered to rodents during "puberty" possibly through induction of proinflammatory responses [50, 51, 69-74]. Excessive signaling through the ER appears to be another primary mechanism for mammary carcinogenesis as modest overexpression of ER $\alpha$ in response to endogenous estrogen during puberty in transgenic mice resulted in mammary hyperplasia and tumors $[75,76]$.

BCERP members are studying the effect of pubertal levels of perfluorooctanoic acid (PFOA) and per- and polyfluoralkyl substances (PFAS) on breast development and breast density. PFAS are used in many commercial products because of their non-stick, stain-resistant, and waterproof characteristics. Sources of human exposure include production facilities, firefighting training, consumer products, diet, and drinking water. Dietary sources include seafood [77] and food packaging [78]. PFAS enhance the estrogenic effects of $17 \beta$-estradiol in T47D human breast cancer cells [79] and promote the proliferation, migration and invasion potential of human breast epithelial cells [80]. Animal studies provide evidence that PFOA affects the developing mammary gland [81], although limited human epidemiologic data have been less conclusive when PFOA and PFAS exposure was examined in relation to intermediate breast cancer markers (hormone levels) [82] or measured during adulthood [83]. Because environmental chemicals may influence the timing and duration of the pubertal trajectory, studies including breast tissue biomarkers that can be reliably measured to provide greater information than a single event in time, such as age at menarche, are critical to move the field forward.

\section{Pregnancy window of susceptibility}

Pregnancy is another period of rapid breast tissue and micro-environmental changes during which susceptibility to environmental exposures may increase the risk of breast cancer [8]. During pregnancy, breast tissue changes rapidly in size and function to prepare for lactation. Estrogen, progesterone, and prolactin are the major drivers of branching and development of the lobuloalveolar structures' characteristic of the mature breast [84]. Pregnancy also decreases the number of mammary stem cells $[85,86]$. However, the protective pathways activated during pregnancy can be eroded by prolonged exposure to exogenous $17 \beta$-estradiol which restores sensitivity to carcinogen-induced mammary tumors [87-89]. These observations may explain why pregnancy is accompanied by a short-term increase in breast cancer risk [12, 90]; "pregnancy-associated breast cancer" has poorer overall survival [91, 92]. However, in the long term after a pregnancy, breast cells are less sensitive to carcinogenesis with the lifetime risk of breast cancer reduced by up to $50 \%$ [93-96]. Thus, the mechanisms mediating the competition between tumor-promoting and tumor-suppressive effects of estrogens in the breast provide fundamental insights into mechanisms underlying risk and resistance in the presence of environmental chemicals.

In mice, there is a greater than 100-fold increase in the number of mammary epithelial cells during pregnancy demonstrating the rapid changes that occur in mammary tissue. Despite the rapid proliferation, a full-term pregnancy renders the mammary epithelium resistant to tumorigenesis subsequent to the pregnancy. This is observed in studies of exposure to carcinogens [70, 97-99] as well as inherited genetic risk alleles [100-103]. Administering exogenous estrogen, either alone or in combination with progesterone to rodents at an early age, sufficiently mimics the effect of pregnancy in reducing tumors in rodents [104-106]. Lobuloalveolar structures may be less susceptible to carcinogens [107, 108], in part, through more robust p53-dependent responses to DNA damage [109].

Epidemiologic evidence directly linking environmental exposures during pregnancy and breast cancer risk arises from the previously mentioned prospective CHDS which measured PCB and DDT soon after pregnancy and confirmed breast cancer diagnoses with medical records. Relative risk estimates for breast cancer comparing upper to lower quartiles of 16 individual PCB congeners ranged from 0.2 to 6.3 ; a composite score of exposure was associated with an odds ratio of 2.8 (95\% CI 1.1-7.1) (Table 1) [110]. Other epidemiologic studies suggest no association between breast cancer and organochlorine pesticide residues in blood collected near the time of diagnosis [111, 112], but these measurements may not be representative of exposure to the parent chemical during the relevant WOS [113].

The BCERP consortium is studying the effects of exposure during pregnancy on maternal breast cancer risk by examining breast tissue changes in the mothers of daughters participating in studies at the Columbia's 
Children Center for Environmental Health [32, 114]. The design of this mother-daughter cohort, similar to CHDS, facilitates efficient examination of exposure to $\mathrm{PAH}$ during two WOS (pregnancy and prenatal) in the two generations [115]. As a complement to this epidemiologic study, other BCERP members aim to elucidate the mechanisms for the dual effect of pregnancy on breast cancer risk by examining chemicals that are found in higher levels among pregnant women $[116,117]$ and their potential to impair the protective pathways associated with breast development during pregnancy. These pathways include the activity of p53 [109] and limiting the stem cell populations [118].

\section{Menopausal transition window of susceptibility}

Although menopause is often defined as the cessation of menstrual periods for at least 1 year, the menopausal transition begins a number of years prior to menopause. During the menopausal transition, micro-environment changes occur in the breast tissue along with declining systemic levels of endogenous estrogen and progesterone [119]. As the majority of breast cancers are responsive to these two sex steroid hormones, their decline explains the leveling-off of the age-specific rate curve of breast cancer after menopause [120]. Later age at menopause is associated with a higher risk of developing breast cancer due to a longer period of exposure to higher levels of sex steroid hormones [121]. Despite the leveling in the age-specific rate curve of breast cancer, the vast majority of breast cancers are diagnosed after menopause, in part through enhanced hormone receptor sensitivity during the menopausal transition. Mammary tissue may be more responsive to lower levels of estrogen and progesterone, as well as to hormone mimics, by adapting to the abrupt reduced production of ovarian hormones [122, 123].

Analyses of data from the Women's Health Initiative (WHI) showed that the increased incidence of breast cancer with use of exogenous estrogen and progesterone [124-127] was mediated through the change in mammographic breast density that occurred in the first year of use [128]. A biologically based breast tumor growth rate model [129] suggests that hormone therapy promotes growth of pre-existing occult lesions and minimally initiated de novo tumors. EDCs with estrogen-like and/or progesterone-like activities or those modifying aromatase expression/activity including polybrominated diphenyl ethers (PBDE), BPA, or selected metals may act in a similar manner and promote the growth of occult disease to clinically detectable tumors during the menopausal transition.

PBDE are a class of over 200 organohalogenated compounds widely used as flame retardants and may modulate steroidogenesis including expression of aromatase [130-136]. BPA is an industrial chemical found in polycarbonate plastics, epoxy resins, dental sealants, and thermal paper [137, 138]. Both PBDE [136] and BPA [139] have been shown to act as ligands of ER $\alpha$. While experimental studies suggest that PBDE and BPA cause breast cancer and biomonitoring studies confirm that women are exposed, epidemiologic studies have not to-date measured exposure during relevant WOS, used methods that reflect longterm exposure, or included measures of mammographic density or other intermediate markers of breast cancer risk [138, 140, 141].

Metalloestrogens are metals that activate the ER, leading to estrogen-like changes. Metalloestrogens are prevalent environmental contaminants with multiple routes of human exposure. They often accumulate in tissues and organs (reviewed in [142, 143]). Most breast cancer studies have focused on cadmium which induces the proliferation of estrogen-dependent breast cancer cells [144-147], increases the transcription and expression of estrogen-regulated genes such as the PR [144, 148], activates ER $\alpha$ in transfection assays [144-146, 149, 150], and increases signaling through the ERK1/2 and Akt pathways $[148,151,152]$. The reported associations between metalloestrogen exposures and breast cancer risk to date have been inconsistent in part due to the variety of techniques used to assess exposure. Studies of dietary cadmium measured from self-reported dietary assessments and breast cancer risk have on the most part found minimal if any associations due in part to the difficulty in determining exposure [153-159]. The studies of neighborhood airborne levels did not distinguish differences between breast cancer cases and controls [160, 161]. The studies measuring individual cadmium levels from blood, urine, or toenails are not necessarily measuring the same timing of exposure. Most [153-155, 159, 162, 163], but not all $[158,164]$, epidemiologic studies of postmenopausal women or all ages combined show risk estimates in the 0.73 to 1.01 range (Table 2). Two studies show greater risk associated with cadmium exposure for premenopausal women than for postmenopausal women [156, 165], whereas two other studies show the reverse [157, 166], with additional studies describing generally null associations for both groups $[160,161,167,168]$. Stratification by estrogen receptor status does not reveal a consistent pattern. Studies of cadmium and mammographic breast density as an intermediate marker of breast cancer risk also have mixed findings possibly due to differences in assessment of cadmium or breast density in terms of methods and in timing relative to WOS [168-171]. Exposure to cadmium or other metalloestrogens during any of the WOS may impact a woman's risk of breast cancer by activation of the hormone receptors; however, no studies 


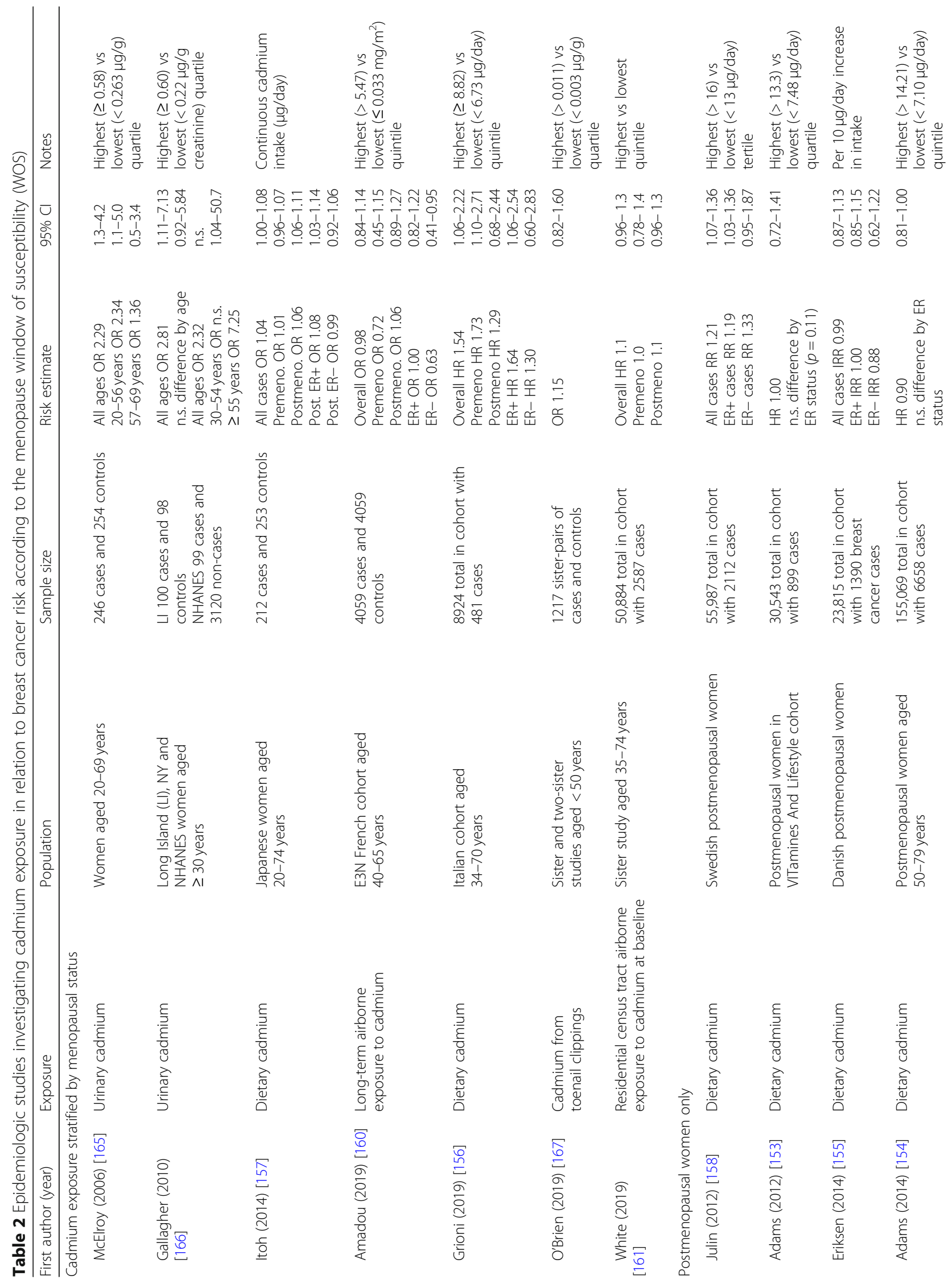


Terry et al. Breast Cancer Research

(2019) 21:96

Page 9 of 16

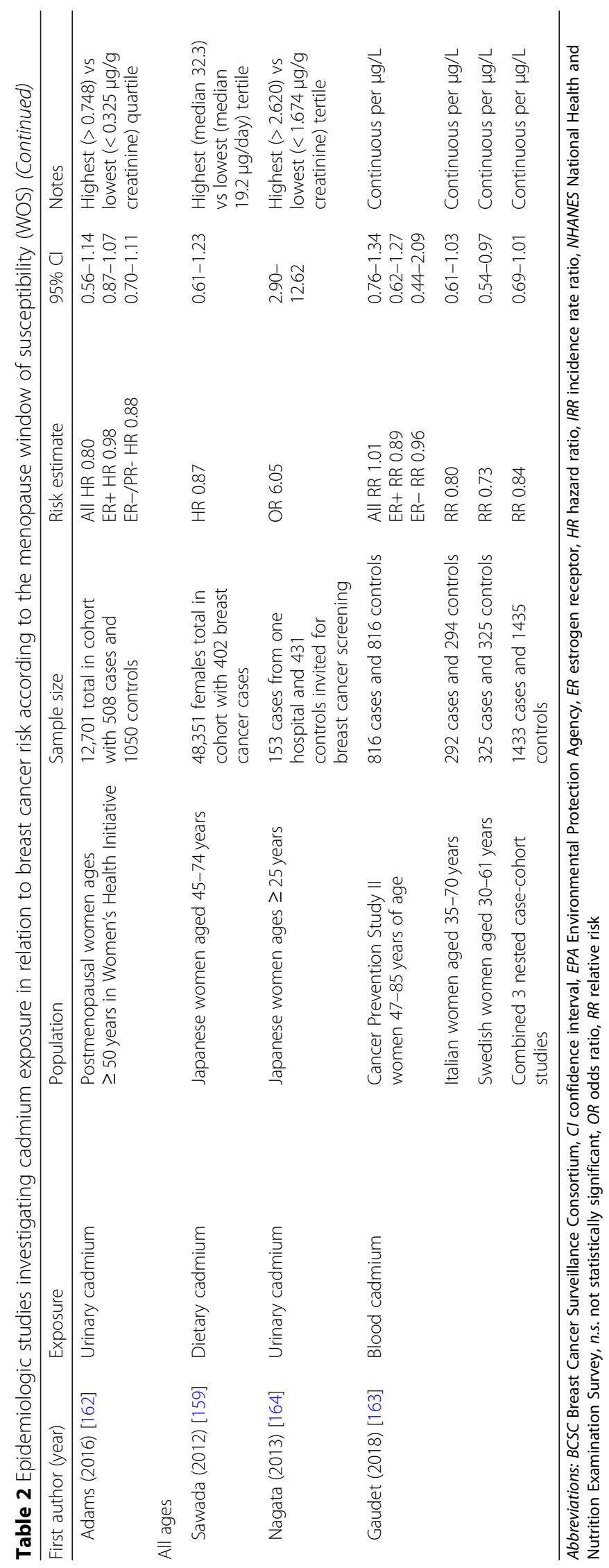


as of yet have carefully examined whether metalloestrogens may have the greatest impact during the menopausal transition when endogenous hormone levels are declining.

BCERP members are examining whether exposure to PBDEs, BPA, or selected metals during the menopausal transition is associated with breast cancer risk in humans, and evaluating potential mechanisms to explain these associations in rodent models.

\section{Strategies to address long latency}

The long time between exposures during the early WOS (prenatal, puberty, pregnancy) and breast cancer occurrence has multiple implications for breast cancer research. First, because many environmental exposures are stored long-term in adipose tissue, even compounds now banned, such as DDT and PBDE, may continue to be relevant for breast cancer risk. Bioaccumulation of lipophilic chemicals and their long-term storage also means studies incorporating biomarkers in breast tissue need to consider both the effects on adipose tissue as well as epithelial and stromal tissues.

Second, because it may be decades after the relevant windows of exposure before breast cancer is diagnosed, the examination and validation of intermediate biomarkers of response, apparent closer to the timing of exposure and before diagnosis, are imperative, particularly in prospective human studies. BCERP first started as a cohort study of the environmental exposures that may accelerate puberty. The main outcome of the cohort study was based on Tanner Stages [172]. As BCERP expanded to include other WOS, additional measures of breast tissue composition and breast density were added. BCERP investigators are now using a variety of intermediate markers-as both outcomes in relation to chemical exposures and as predictors of breast and mammary cancers-conducted in parallel human and rodent studies including epigenetic biomarkers, altered tumor suppression and induction, and altered estrogen signaling and biosynthesis (Fig. 1) [173].

One intermediate outcome is mammographic breast density (MBD), defined as the fraction of connective and glandular tissue to adipose tissue on a mammogram [174-181]. MBD is one of the strongest predictors of breast cancer risk with a four- to sixfold elevation in risk comparing $\geq 75 \%$ MBD to $<5 \%$ [182], but the mechanisms explaining how environmental chemicals affect the overall level and rate of change of MBD are uncertain. While MBD declines with age in many women, particularly around the time of menopause [183-185], this pattern does not occur uniformly for all women [8, 186, 187].

Little is known of the drivers of breast tissue changes across adolescence, early adulthood, and the menopausal transition and thus the contributors to breast density.
Most of what is known about normal breast tissue characteristics is from mammography data in women over 40 years of age. In women under 40 years, two alternative imaging methods have been used to assess breast composition including three studies of magnetic resonance imaging (MRI) in women aged $15-30$ years [188-190] and two of dual X-ray absorptiometry (DXA) in girls aged 10-16 years [191, 192]. In addition, optical spectroscopy (OS) provides a compositional view of the breast capturing variation in the amount of water, lipid, hemoglobin, and collagen, as well as overall cellular and connective tissue density [174-176]. Collagen density may promote epithelial cell proliferation and increase tumor mobility and invasion, while hemoglobin is associated with angiogenesis [193-195]. OS has been used to measure differences in adolescent breast tissue across developmental stages as assessed by Tanner stage [196]. Thus, MRI, DXA, and OS provide novel intermediate outcomes to measure breast tissue changes across the developmental trajectory of adolescence and early adulthood and may be important tools for examining environmental effects during these life stages. Mammography techniques now include digital breast tomosynthesis measures as well as the use of ultrasound in measuring breast density without radiation exposure [181]. While density of the adult breast is highly correlated with breast cancer risk, longitudinal measures of pubertal density are currently lacking but are being collected in BCERP.

\section{Conclusions}

Given the changes in mammary tissue architecture and hormone signaling during the prenatal, pubertal, pregnancy, and menopausal transition windows, these critical time periods may reflect windows of heightened risk. Thus, measuring the impact of environmental chemical and metal exposures during these WOS is essential to understand their roles in breast cancer risk; these issues have not been addressed by the majority of epidemiologic studies to date.

Experimental studies in cell lines and animals are providing causative mechanistic links between environmental exposures and altered mammary carcinogenesis, particularly during key WOS. Increasingly, epidemiologic studies are able to link the human exposure of chemicals and metals during relevant WOS through the use of intermediate breast outcomes including specific breast tissue characteristics and breast density in adolescence and adulthood to address the challenge of long latency time posed in cancer research.

For many of the studies described here, community engagement strengthens the research design as well as the dissemination and implementation of study findings. To address knowledge gaps and accelerate translation of environmental breast cancer research findings related to 
WOS, BCERP integrates basic and population researchers with communication scientists and representatives of community-based organizations (Fig. 1). Community partnerships are vital, because both the sources and the remedies for environmental exposures are outside of clinical settings. Community input also can identify issues of concern to the community, motivate participation in studies, and translate findings to public audiences. Scientists need to disseminate research findings to the public to enable people to make informed choices in their personal lives and workplaces, and to influence health policies as voters and community leaders. For example, participation of community partners in BCERP has led to the development of strategies to provide reports of personal chemical exposures to individuals who donated biological samples, so they can learn about environmental health and make informed decisions regarding possible behavioral modification in general and with particular reference to WOS [197, 198]. Digital methods using libraries of vetted exposure and health information and decision rules, set by the study team, make personalized results practical [199]. In addition, communication scientists within BCERP are testing different messages and channels for future outreach efforts [200]. Scholarship about community-engaged research shows that this approach improves the "rigor, relevance, and reach" of research [201].

Although the median age when women are diagnosed with breast cancer is 62 years [202], primary prevention of potentially hazardous environmental exposures during earlier WOS is critical [13], particularly when considering that exposure to environmental chemicals may contribute to cancer health disparities [203-206]. Furthermore, just as family-based studies facilitated the discovery of breast cancer genes relevant to all women, studies during specific WOS will facilitate the assessment of the effects from environmental exposures that will be relevant outside of these WOS. As evidence from WOS accumulates, the paradigm for breast cancer needs to expand beyond the secondary prevention efforts of screening and mid-life risk assessment to primary prevention efforts with involvement of community partners, educators and school districts, families, and primary care providers including pediatricians for lifelong impact [207].

\footnotetext{
Abbreviations

BCERP: Breast Cancer and the Environment Research Program;

BPA: Bisphenol A; CHDS: Child Health and Development Study; DDT: Dichlorodiphenyltrichloroethane; DMBA: Dimethylbenz [a]anthracene;

DNA: Deoxyribonucleic acid; DXA: Dual X-ray absorptiometry; EDC: Endocrine-disrupting chemical; ER: Estrogen receptor;

MBD: Mammographic breast density; MRI: Magnetic resonance imaging; NCI: National Cancer Institute; NIEHS: National Institute of Environmental Health Sciences; OR: Odds ratio OSoptical spectroscopy; PAH: Polycyclic aromatic hydrocarbons; PBDE: Polybrominated diphenyl ethers;

PCB: Polychlorinated biphenyl; PFAS: Per- and poly-fluoroalkyl substances;
}

PFOA: Perfluorooctanoic acid; RR: Relative risk; WHI: Women's Health Initiative

\section{Acknowledgements}

The authors would like to thank Natalia Arroyo, Julie McGregor, and Eileen McGuine for their assistance with this manuscript. The funders had no role in the design of the study, the writing of the manuscript, or the decision to submit the manuscript for publication.

The Breast Cancer and the Environment Research Program includes Mary Pat Berry, Jennifer Bird, Christopher Bradfield, Ronald Gangnon, Michael Gould, John Hampton, Sara Lindberg, Sarah Luongo, Kristen Malecki, Betsy Rolland, and James Shull (University of Wisconsin-Madison); Mia Gaudet (American Cancer Society); Mark Thornquist (Fred Hutchinson Cancer Research Center); Mark D. Aupperlee, Sandra Z. Haslam, Reyhane Hoshyar, Anastasia Kariagina, Juliana R. Lopes, Karen J. Miller, Olena Morozova, Cathy J. Newkirk, Richard C. Schwartz, Brandon Thomas, Daniel Totzkay, and Fang Xie (Michigan State University); Kami J. Silk (University of Delaware); Frank M. Biro (Cincinnati Children's Hospital); Cecily S. Fassler, Courtney M. Giannini, and Susan Pinney (University of Cincinnati); Melissa A. Troester (University of North Carolina Chapel Hill); Kimberly Burke, Julie Herbstman, Rebecca Kehm, Jasmine McDonald, Rachel Miller, Sabine Oskar, Frederica Perera, Debeshish Sahay, Parisa Tehranifar, Mary Beth Terry, Desiree Walker, and Nur Zeinomar (Columbia University); Milagros de Hoz and Peggy Shepard (WeACT); Julia Knight (Lunenfeld-Tanenbaum Research Institute); Lothar Lilge (University Health Network); Alexandra Binder, Karin Michels (University of California Los Angeles); Vincent Bessonneau, Julia Brody, Vanessa De La Rosa, Jennifer Ohayon, and Ruthann Rudel (Silent Spring Institute); Camila Corvalan, Ana Pereira, and Rosario Toro-Campos (University of Chile); Julia Pereira, Jose Russo, and Su Yanrong (Fox Chase Cancer Center); John Shepherd (University of Hawaii Cancer Center); Lucile Adams-Campbell, Chiranjeev Dash, Bassem Haddad, Rhonda Hamilton, Mary Beth Martin, and Brenda Richardson (Georgetown University); Celia Byrne and Hristina Denic-Roberts (Uniformed Services University of the Health Sciences); Gregory Chang, Shiuan Chen, Yuan Chun Ding, Noriko Kanaya, Susan Neuhausen, Michele Rakoff, Kohei Saeki, and Mayra Serrano (City of Hope); Peggy Reynolds (University of California San Francisco); Karen Dunphy, Joseph Jerry, Anna Symington, and Laura Vandenberg (University of Massachusetts Amherst); Sallie Schneider (Baystate Medical Center); Swann Arp Adams, Heather M. Brandt, Daniela Friedman, and Jamie R. Lead (University of South Carolina); Xiaomei Cai, Gary Kreps, Camella J. Rising, and Kevin B. Wright (George Mason University); Amelia Burke-Garcia (University of Chicago); Dasha Afanaseva (Westat); and Carla L. Fisher and Michaela Devyn Mullis (University of Florida).

\section{Disclosure}

Celia Byrne: the views expressed are those of the author(s) and do not necessarily reflect the official views of the Uniformed Services University of the Health Sciences or the Department of Defense.

\section{Authors' contributions}

All authors performed parts of the literature review and wrote drafts of the manuscript. MBT, KBM, and ATD conceptualized the paper and provided overall supervision and coordination of the manuscript preparation. ATD generated the table and figures, which were revised by all authors. All authors were involved in writing the manuscript and approved the final manuscript.

\section{Funding}

This work was completed as part of the Breast Cancer and the Environment Research Program (BCERP), supported by the National Institute of Environmental Health Sciences and the National Cancer Institute at the National Institutes of Health (grant numbers U01 ES026119, U01 ES026122, U01 ES026127, U01 ES026130, U01 ES026132, U01 ES026137, U01 ES026140, R03 ES027406, R21 ES027417, and R21 ES027418).

\section{Availability of data and materials}

Not applicable.

Ethics approval and consent to participate Not applicable. 


\section{Competing interests}

The authors declare that they have no competing interests.

\section{Author details}

'Department of Epidemiology, Mailman School of Public Health, Columbia University, 722 West 168th Street, Room 1611, New York, NY 10032, USA. 2Department of Epidemiology, Fielding School of Public Health, University of California, 650 Charles E. Young Drive South, CHS 71-254, Los Angeles, CA 90095, USA. ${ }^{3}$ Silent Spring Institute, 320 Nevada St., Newton, MA 02460, USA. ${ }^{4}$ Department of Preventive Medicine and Biostatistics, Uniformed Services University of the Health Sciences, 4301 Jones Bridge Road A-1039F, Bethesda, MD 20814, USA. ${ }^{5}$ Department of Cancer Biology, Beckman Research Institute of City of Hope, 1450 E. Duarte Road, Duarte, CA 91010, USA. 'Pioneer Valley Life Sciences Institute and Department of Veterinary \& Animal Sciences, University of Massachusetts Amherst, 661 North Pleasant St., Amherst, MA 01003, USA. ${ }^{7}$ Department of Population Health Sciences and the Carbone Cancer Center, School of Medicine and Public Health, University of Wisconsin-Madison, 610 Walnut St., WARF Room 605, Madison, WI 53726, USA. ${ }^{8}$ Departments of Oncology and Biochemistry \& Molecular Biology, Georgetown University Medical Center, E411 New Research Building, Washington, DC 20057, USA. 'Departments of Medicine, Pediatrics, Environmental Health Sciences; Vagelos College of Physicians and Surgeons, Mailman School of Public Health, Columbia University, PH8E-101B, 630 W. 168th St, New York, NY 10032, USA. ${ }^{10}$ Department of Population Sciences, Beckman Research Institute of City of Hope, 1450 E. Duarte Road, 1500 E. Duarte Road, Duarte, CA 91010, USA. "'Department of Communication, University of Delaware, 250 Pearson Hall, 125 Academy St, Newark, DE 19716, USA. ${ }^{12}$ Department of Population Health Sciences and Carbone Cancer Center, School of Medicine and Public Health, University of Wisconsin-Madison, 610 Walnut St., WARF Room 307, Madison, WI 53726, USA.

\section{Published online: 20 August 2019}

\section{References}

1. Lee PN, Forey BA, Coombs KJ. Systematic review with meta-analysis of the epidemiological evidence in the 1900s relating smoking to lung cancer. BMC Cancer. 2012;12:385

2. Walboomers JM, Jacobs MV, Manos MM, Bosch FX, Kummer JA, Shah KV, Snijders PJ, Peto J, Meijer CJ, Munoz N. Human papillomavirus is a necessary cause of invasive cervical cancer worldwide. J Pathol. 1999;189(1):12-9.

3. Breast Cancer Risk and Prevention. Available at https://www.cancer.org/ cancer/breast-cancer/risk-and-prevention.html. Accessed 3 July 2019.

4. Colditz GA, Bohlke K. Priorities for the primary prevention of breast cancer. CA Cancer J Clin. 2014;64(3):186-94

5. Sprague BL, Trentham-Dietz A, Egan KM, Titus-Ernstoff L, Hampton JM Newcomb PA. Proportion of invasive breast cancer attributable to risk factors modifiable after menopause. Am J Epidemiol. 2008;168(4):404-11.

6. IOM (Institute of Medicine). Breast cancer and the environment: a life course approach. Washington, D.C.: National Academies Press; 2012.

7. Korenman SG. The endocrinology of breast cancer. Cancer. 1980;46(4 Suppl):874-8

8. Pike MC, Krailo MD, Henderson BE, Casagrande JT. Hoel DG: 'Hormonal' risk factors, 'breast tissue age' and the age-incidence of breast cancer. Nature. 1983;303(5920):767-70

9. Russo J, Russo IH. Toward a physiological approach to breast cancer prevention. Cancer Epidemiol Biomark Prev. 1994;3(4):353-64.

10. Hilakivi-Clarke L. Maternal exposure to diethylstilbestrol during pregnancy and increased breast cancer risk in daughters. Breast Cancer Res. 2014;16(2):208.

11. Nechuta S, Paneth N, Velie EM. Pregnancy characteristics and maternal breast cancer risk: a review of the epidemiologic literature. Cancer Causes Control. 2010;21(7):967-89.

12. Nichols HB, Schoemaker MJ, Cai J, XU J, Wright LB, Brook MN, Jones ME, Adami HO, Baglietto L, Bertrand KA, et al. Breast cancer risk after recent childbirth: a pooled analysis of 15 prospective studies. Ann Intern Med. 2018. https://doi.org/10.7326/M18-1323.

13. Interagency Breast Cancer and the Environment Research Coordinating Committee. In. Breast cancer and the environment: prioritizing prevention. Bethesda, MD: National Institutes of Health; February 2013. (http://www.niehs. nih.gov/about/assets/docs/ibcercc_full_508.pdf). (Accessed 1 Dec 2014).
14. Rodgers KM, Udesky JO, Rudel RA, Brody JG. Environmental chemicals and breast cancer: an updated review of epidemiological literature informed by biological mechanisms. Environ Res. 2018;160:152-82.

15. Fenton SE, Reed C, Newbold RR. Perinatal environmental exposures affect mammary development, function, and cancer risk in adulthood. Annu Rev Pharmacol Toxicol. 2012;52:455-79.

16. Russo J, Lynch H, Russo IH. Mammary gland architecture as a determining factor in the susceptibility of the human breast to cancer. Breast J. 2001;7(5): 278-91.

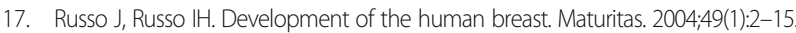

18. Schmidt CW. IOM issues report on breast cancer and the environment. Environ Health Perspect. 2012;120(2):a60-1.

19. Brody JG, Rudel RA, Michels KB, Moysich KB, Bernstein L, Attfield KR, Gray S. Environmental pollutants, diet, physical activity, body size, and breast cancer: where do we stand in research to identify opportunities for prevention? Cancer. 2007;109(12 Suppl):2627-34

20. Michels KB, Xue F, Terry KL, Willett WC. Longitudinal study of birthweight and the incidence of breast cancer in adulthood. Carcinogenesis. 2006; 27(12):2464-8

21. Warner ET, Hu R, Collins LC, Beck AH, Schnitt S, Rosner B, Eliassen AH, Michels KB, Willett WC, Tamimi RM. Height and body size in childhood, adolescence, and young adulthood and breast cancer risk according to molecular subtype in the Nurses' Health Studies. Cancer Prev Res (Phila). 2016;9(9):732-8

22. Michels KB, Mohllajee AP, Roset-Bahmanyar E, Beehler GP, Moysich KB. Diet and breast cancer: a review of the prospective observational studies. Cancer. 2007;109(12 Suppl):2712-49.

23. Potischman N, Troisi R. In-utero and early life exposures in relation to risk of breast cancer. Cancer Causes Control. 1999;10(6):561-73.

24. Xue F, Michels KB. Intrauterine factors and risk of breast cancer: a systematic review and meta-analysis of current evidence. Lancet Oncol. 2007;8(12):1088-100.

25. Cohn BA, La Merrill M, Krigbaum NY, Yeh G, Park JS, Zimmermann L, Cirillo PM. DDT exposure in utero and breast cancer. J Clin Endocrinol Metab. 2015;100(8):2865-72.

26. Mrema EJ, Rubino FM, Brambilla G, Moretto A, Tsatsakis AM, Colosio C. Persistent organochlorinated pesticides and mechanisms of their toxicity. Toxicology. 2013;307:74-88.

27. Rudel RA, Seryak LM, Brody JG. PCB-containing wood floor finish is a likely source of elevated PCBs in residents' blood, household air and dust: a case study of exposure. Environ Health. 2008;7:2.

28. Phillips D. Polycyclic aromatic hydrocarbons in the diet. Mutat Res. 1999; 443(1-2):139-47.

29. Miguel A, Kirchstetter T, Harley R. On-road emissions of particulate polycyclic aromatic hydrocarbons and black carbon from gasoline and diesel vehicles. Environmental Science \& Technology. 1998;32(4):450-5.

30. IARC: Polynuclear aromatic hydrocarbons. Part 3, Industrial exposures in aluminum production, coal gasification, coke production, and iron and steel founding. International Agency for Research on Cancer Monographs on the Carcinogenic Risk of Chemicals to Humans. Lyon; 1984.

31. Pedersen M, Wichmann J, Autrup H, Dang D, Decordier I, Hvidberg M, Bossi $\mathrm{R}$, Jakobsen J, Loft S, Knudsen L. Increased micronuclei and bulky DNA adducts in cord blood after maternal exposures to traffic-related air pollution. Environ Res. 2009:109(8):1012-20.

32. Bocskay KA, Tang D, Orjuela MA, Liu X, Warburton DP, Perera FP. Chromosomal aberrations in cord blood are associated with prenatal exposure to carcinogenic polycyclic aromatic hydrocarbons. Cancer Epidemiol Biomark Prev. 2005;14(2):506-11.

33. Bonner MR, Han D, Nie J, Rogerson P, Vena JE, Muti P, Trevisan M, Edge SB, Freudenheim $\mathrm{J}$. Breast cancer risk and exposure in early life to polycyclic aromatic hydrocarbons using total suspended particulates as a proxy measure. Cancer Epidemiol Biomark Prev. 2005;14(1):53-60.

34. Agency for Toxic Substances and Disease Registry (ATSDR). Toxicological profile for polycyclic aromatic hydrocarbons (PAHs). Atlanta: U.S. Department of Health and Human Services, Public Health Service; 1995.

35. IARC. Volume 82. Some traditional herbal medicines, some mycotoxins, naphthalene and styrene. In: IARC Monographs on the Evaluation of Carcinogenic Risks to Humans. Lyon: World Health Organization; 2002.

36. Obana H, Hori S, Kashimoto T, Kunita N. Polycyclic aromatic hydrocarbons in human fat and liver. Bull Environ Contam Toxicol. 1981;27(1):23-7.

37. Plísková M, Vondrácek J, Vojtesek B, Kozubík A, Machala M. Deregulation of cell proliferation by polycyclic aromatic hydrocarbons in 
human breast carcinoma MCF-7 cells reflects both genotoxic and nongenotoxic events. Toxicol Sci. 2004;83(2):246-56.

38. Ambrosone C, Shields P. Molecular epidemiology of breast cancer. In: Aldaz C, Gould M, McLachlan J, Slaga T, editors. Etiology of Breast and gynecological cancers (Progress in clinical and biologic research). New York: Wiley-Liss, Inc.; 1997. p. 93-9.

39. Gammon MD, Santella RM, Neugut Al, Eng SM, Teitelbaum SL, Paykin A, Levin B, Terry MB, Young TL, Wang LW, et al. Environmental toxins and breast cancer on Long Island. I. Polycyclic aromatic hydrocarbon DNA adducts. Cancer Epidemiol Biomark Prev. 2002;11(8):677-85.

40. Rundle A, Tang DL, Hibshoosh H, Estabrook A, Schnabel F, Cao WF, Grumet S, Perera FP. The relationship between genetic damage from polycyclic aromatic hydrocarbons in breast tissue and breast cancer. Carcinogenesis. 2000;21(7):1281-9.

41. Korsh J, Shen A, Aliano K, Davenport T. Polycyclic aromatic hydrocarbons and breast cancer: a review of the literature. Breast Care (Basel). 2015;10(5):316-8.

42. White A, Teitelbaum S, Stellman S, Beyea J, Steck S, Mordukhovich I, McCarty K, Ahn J, Rossner P, Santella R, et al. Indoor air pollution exposure from use of indoor stoves and fireplaces in association with breast cancer: a case-control study. Environ Health. 2014;13(1):108.

43. White AJ, Sandler DP. Indoor wood-burning stove and fireplace use and breast cancer in a prospective cohort study. Environ Health Perspect. 2017; 125(7):077011.

44. Mordukhovich I, Beyea J, Herring AH, Hatch M, Stellman SD, Teitelbaum SL, Richardson DB, Millikan RC, Engel LS, Shantakumar S, et al. Vehicular trafficrelated polycyclic aromatic hydrocarbon exposure and breast cancer incidence: the Long Island Breast Cancer Study Project (LIBCSP). Environ Health Perspect. 2016;124(1):30-8.

45. Agudo A, Peluso M, Munnia A, Lujan-Barroso L, Barricarte A, Amiano P, Navarro C, Sanchez MJ, Quiros JR, Ardanaz E, et al. Aromatic DNA adducts and breast cancer risk: a case-cohort study within the EPIC-Spain. Carcinogenesis. 2017;38(7):691-8.

46. Lee KH, Shu XO, Gao YT, Ji BT, Yang G, Blair A, Rothman N, Zheng W, Chow WH, Kang D. Breast cancer and urinary biomarkers of polycyclic aromatic hydrocarbon and oxidative stress in the Shanghai Women's Health Study. Cancer Epidemiol Biomark Prev. 2010;19(3):877-83.

47. Miller RL, Yan Z, Maher C, Zhang H, Gudsnuk K, McDonald J, Champagne FA. Impact of prenatal polycyclic aromatic hydrocarbon exposure on behavior, cortical gene expression and DNA methylation of the Bdnf gene. Neuroepigenetics. 2016;5:11-8.

48. Rundle A, Hoepner L, Hassoun A, Oberfield S, Freyer G, Holmes D, Reyes M, Quinn J, Camann D, Perera F, et al. Association of childhood obesity with maternal exposure to ambient air polycyclic aromatic hydrocarbons during pregnancy. Am J Epidemiol. 2012;175(11):1163-72.

49. Yan Z, Zhang H, Maher C, Arteaga-Solis E, Champagne FA, Wu L, McDonald JD, Yan B, Schwartz GJ, Miller RL. Prenatal polycyclic aromatic hydrocarbon, adiposity, peroxisome proliferator-activated receptor (PPAR) gamma methylation in offspring, grand-offspring mice. PLOS One. 2014;9(10):e110706.

50. Russo J, Tay LK, Russo IH. Differentiation of the mammary gland and susceptibility to carcinogenesis. Breast Cancer Res Treat. 1982;2(1):5-73.

51. Russo J, Wilgus G, Russo $1 \mathrm{H}$. Susceptibility of the mammary gland to carcinogenesis: I Differentiation of the mammary gland as determinant of tumor incidence and type of lesion. Am J Pathol. 1979;96(3):721-36.

52. Mallepell S, Krust A, Chambon P, Brisken C. Paracrine signaling through the epithelial estrogen receptor alpha is required for proliferation and morphogenesis in the mammary gland. Proc Natl Acad Sci U S A. 2006; 103(7):2196-201.

53. Feng Y, Manka D, Wagner KU, Khan SA. Estrogen receptor-alpha expression in the mammary epithelium is required for ductal and alveolar morphogenesis in mice. Proc Natl Acad Sci U S A. 2007;104(37):14718-23.

54. Prins GS, Calderon-Gierszal EL, Hu WY. Stem cells as hormone targets that lead to increased cancer susceptibility. Endocrinology. 2015;156(10): 3451-7.

55. Ercan C, van Diest PJ, Vooijs M. Mammary development and breast cancer: the role of stem cells. Curr Mol Med. 2011;11(4):270-85.

56. Mervish NA, Pajak A, Teitelbaum SL, Pinney SM, Windham GC, Kushi LH, Biro FM, Valentin-Blasini L, Blount BC, Wolff MS, et al. Thyroid antagonists (perchlorate, thiocyanate, and nitrate) and childhood growth in a longitudinal study of U.S. girls. Environ Health Perspect. 2016;124(4):542-9.
57. Wolff MS, Teitelbaum SL, McGovern K, Pinney SM, Windham GC, Galvez M, Pajak A, Rybak M, Calafat AM, Kushi LH, et al. Environmental phenols and pubertal development in girls. Environ Int. 2015;84:174-80.

58. Wolff MS, Teitelbaum SL, McGovern K, Windham GC, Pinney SM, Galvez M, Calafat AM, Kushi LH, Biro FM, Breast C, et al. Phthalate exposure and pubertal development in a longitudinal study of US girls. Hum Reprod. 2014;29(7):1558-66.

59. Wolff MS, Teitelbaum SL, Pinney SM, Windham G, Liao L, Biro F, Kushi LH, Erdmann C, Hiatt RA, Rybak ME, et al. Investigation of relationships between urinary biomarkers of phytoestrogens, phthalates, and phenols and pubertal stages in girls. Environ Health Perspect. 2010;118(7):1039-46.

60. Windham GC, Pinney SM, Voss RW, Sjodin A, Biro FM, Greenspan LC, Stewart S, Hiatt RA, Kushi LH. Brominated flame retardants and other persistent organohalogenated compounds in relation to timing of puberty in a longitudinal study of girls. Environ Health Perspect. 2015 123(10):1046-52.

61. Bhatia S, Robison LL, Oberlin O, Greenberg M, Bunin G, Fossati-Bellani F Meadows AT. Breast cancer and other second neoplasms after childhood Hodgkin's disease. N Engl J Med. 1996;334(12):745-51.

62. Land CE. Studies of cancer and radiation dose among atomic bomb survivors. The example of breast cancer. JAMA. 1995;274(5):402-7.

63. Ahlgren M, Melbye M, Wohlfahrt J, Sorensen TI. Growth patterns and the risk of breast cancer in women. N Engl J Med. 2004;351(16):1619-26.

64. Harris HR, Willett WC, Vaidya RL, Michels KB. An adolescent and early adulthood dietary pattern associated with inflammation and the incidence of breast cancer. Cancer Res. 2017;77(5):1179-87.

65. Michels KB, Ekbom A. Caloric restriction and incidence of breast cancer. JAMA. 2004;291(10):1226-30.

66. van den Brandt PA, Spiegelman D, Yaun SS, Adami HO, Beeson L, Folsom AR, Fraser G, Goldbohm RA, Graham S, Kushi L, et al. Pooled analysis of prospective cohort studies on height, weight, and breast cancer risk. Am J Epidemiol. 2000;152(6):514-27.

67. Cohn BA, Wolff MS, Cirillo PM, Sholtz RI. DDT and breast cancer in young women: new data on the significance of age at exposure. Environ Health Perspect. 2007;115(10):1406-14.

68. Cohn BA, Cirillo PM, Terry MB. DDT and breast cancer: prospective study of induction time and susceptibility windows. J Natl Cancer Inst. 2019;111(8):djy198.

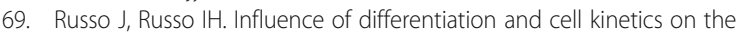
susceptibility of the rat mammary gland to carcinogenesis. Cancer Res. 1980;40(8 Pt 1):2677-87.

70. Russo J, Russo $\mathrm{IH}$. Susceptibility of the mammary gland to carcinogenesis. II. Pregnancy interruption as a risk factor in tumor incidence. Am J Pathol. 1980;100(2):497-512.

71. Russo J, Russo $\mathrm{H}$. Biological and molecular bases of mammary carcinogenesis. Lab Investig. 1987:57(2):112-37.

72. Russo J, Tay LK, Ciocca DR, Russo IH. Molecular and cellular basis of the mammary gland susceptibility to carcinogenesis. Environ Health Perspect. 1983:49:185-99.

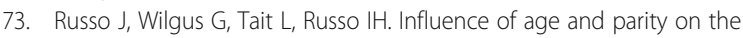
susceptibility of rat mammary gland epithelial cells in primary cultures to 7,12-dimethylbenz(a)anthracene. In Vitro. 1981;17(10):877-84.

74. Tay LK, Russo J. Formation and removal of 7,12-dimethylbenz [a]anthracene--nucleic acid adducts in rat mammary epithelial cells with different susceptibility to carcinogenesis. Carcinogenesis. 1981;2(12):1327-33.

75. Frech MS, Halama ED, Tilli MT, Singh B, Gunther EJ, Chodosh LA, Flaws JA, Furth PA. Deregulated estrogen receptor alpha expression in mammary epithelial cells of transgenic mice results in the development of ductal carcinoma in situ. Cancer Res. 2005;65(3):681-5.

76. Jones LP, Tilli MT, Assefnia S, Torre K, Halama ED, Parrish A, Rosen EM, Furth PA. Activation of estrogen signaling pathways collaborates with loss of Brca1 to promote development of ERalpha-negative and ERalpha-positive mammary preneoplasia and cancer. Oncogene. 2008;27(6):794-802.

77. Christensen KY, Raymond M, Blackowicz M, Liu Y, Thompson BA, Anderson HA, Turyk M. Perfluoroalkyl substances and fish consumption. Environ Res. 2017;154:145-51.

78. Schaider LA, Balan SA, Blum A, Andrews DQ, Strynar MJ, Dickinson ME, Lunderberg DM, Lang JR, Peaslee GF. Fluorinated compounds in US fast food packaging. Environ Sci Technol Lett. 2017;4(3):105-11.

79. Sonthithai P, Suriyo T, Thiantanawat A, Watcharasit P, Ruchirawat M, Satayavivad J. Perfluorinated chemicals, PFOS and PFOA, enhance the 
estrogenic effects of 17beta-estradiol in T47D human breast cancer cells. J Appl Toxicol. 2016;36(6):790-801.

80. Pierozan P, Jerneren F, Karlsson O. Perfluorooctanoic acid (PFOA) exposure promotes proliferation, migration and invasion potential in human breast epithelial cells. Arch Toxicol. 2018;92(5):1729-39.

81. Rudel RA, Fenton SE, Ackerman JM, Euling SY, Makris SL. Environmental exposures and mammary gland development: state of the science, public health implications, and research recommendations. Environ Health Perspect. 2011;119(8):1053-61.

82. Tsai MS, Lin CY, Lin CC, Chen MH, Hsu SH, Chien KL, Sung FC, Chen PC, Su TC. Association between perfluoroalkyl substances and reproductive hormones in adolescents and young adults. Int J Hyg Environ Health. 2015; 218(5):437-43.

83. Bonefeld-Jorgensen EC, Long M, Fredslund SO, Bossi R, Olsen J. Breast cancer risk after exposure to perfluorinated compounds in Danish women: a case-control study nested in the Danish National Birth Cohort. Cancer Causes Control. 2014;25(11):1439-48.

84. David B, Fenton S. Chapter 61 - Mammary gland. In: Hascheck WM, Rousseaux CG, Wallig MA, Bolon B, Ochoa R, Mahler BW, editors. Hascheck and Rousseaux's handbook of toxicologic pathology, volume III. 3rd ed. New York: Academic Press; 2013.

85. Meier-Abt F, Bentires-Alj M. How pregnancy at early age protects against breast cancer. Trends Mol Med. 2014;20(3):143-53.

86. Meier-Abt F, Brinkhaus $H$, Bentires-Alj M. Early but not late pregnancy induces lifelong reductions in the proportion of mammary progesterone sensing cells and epithelial Wnt signaling. Breast Cancer Res. 2014;16(2):402.

87. Rajkumar L, Arumugam A, Elsayed A, Schecter S, Kotkowski E, Castillo R, de la Torre A, Hernandez C. Long-term hormonal promotion overcomes genetic resistance to mammary cancer. Steroids. 2011;76(1-2):31-7.

88. Swanson SM, Guzman RC, Collins G, Tafoya P, Thordarson G, Talamantes F, Nandi S. Refractoriness to mammary carcinogenesis in the parous mouse is reversible by hormonal stimulation induced by pituitary isografts. Cancer Lett. 1995;90(2):171-81.

89. Thordarson G, Van Horn K, Guzman RC, Nandi S, Talamantes F. Parous rats regain high susceptibility to chemically induced mammary cancer after treatment with various mammotropic hormones. Carcinogenesis. 2001;22(7): 1027-33.

90. Schedin P. Pregnancy-associated breast cancer and metastasis. Nat Rev Cancer. 2006;6(4):281-91.

91. Azim HA Jr, Santoro L, Russell-Edu W, Pentheroudakis G, Pavlidis N, Peccatori FA. Prognosis of pregnancy-associated breast cancer: a metaanalysis of 30 studies. Cancer Treat Rev. 2012;38(7):834-42.

92. Callihan EB, Gao D, Jindal S, Lyons TR, Manthey E, Edgerton S, Urquhart A, Schedin P, Borges VF. Postpartum diagnosis demonstrates a high risk for metastasis and merits an expanded definition of pregnancy-associated breast cancer. Breast Cancer Res Treat. 2013;138(2):549-59.

93. Albrektsen G, Heuch I, Hansen S, Kvale G. Breast cancer risk by age at birth, time since birth and time intervals between births: exploring interaction effects. Br J Cancer. 2005;92(1):167-75.

94. Chie WC, Hsieh C, Newcomb PA, Longnecker MP, Mittendorf R, Greenberg ER, Clapp RW, Burke KP, Titus-Ernstoff L, Trentham-Dietz A, et al. Age at any full-term pregnancy and breast cancer risk. Am J Epidemiol. 2000;151(7): 715-22.

95. MacMahon B, Cole P, Lin TM, Lowe CR, Mirra AP, Ravnihar B, Salber EJ, Valaoras VG, Yuasa S. Age at first birth and breast cancer risk. Bull World Health Organ. 1970;43(2):209-21.

96. Rosner B, Colditz GA, Willett WC. Reproductive risk factors in a prospective study of breast cancer: the Nurses' Health Study. Am J Epidemiol. 1994; 139(8):819-35

97. Ronckers CM, Erdmann CA, Land CE. Radiation and breast cancer: a review of current evidence. Breast Cancer Res. 2005;7(1):21-32.

98. Russo $\mathrm{H}$, Russo J. Developmental stage of the rat mammary gland as determinant of its susceptibility to 7,12-dimethylbenz [a]anthracene. J Natl Cancer Inst. 1978;61(6):1439-49.

99. Sinha DK, Pazik JE, Dao TL. Prevention of mammary carcinogenesis in rats by pregnancy: effect of full-term and interrupted pregnancy. $\mathrm{Br} J$ Cancer. 1988;57(4):390-4.

100. Munford RE. Changes in the mammary glands of rats and mice during pregnancy, lactation and involution. 2. Levels of deoxyribonucleic acid, and alkaline and acid phosphatases. J Endocrinol. 1963;28:17-34.
101. Antonio AC, Shenton A, Maher ER, Watson E, Woodward E, Lalloo F, Easton DF, Evans DG. Parity and breast cancer risk among BRCA1 and BRCA2 mutation carriers. Breast Cancer Res. 2006;8(6):R72.

102. Jerry DJ, Kittrell FS, Kuperwasser C, Laucirica R, Dickinson ES, Bonilla PJ, Butel JS, Medina D. A mammary-specific model demonstrates the role of the p53 tumor suppressor gene in tumor development. Oncogene. 2000;19(8):1052-8.

103. Milne RL, Osorio A, Ramon y Cajal T, Baiget M, Lasa A, Diaz-Rubio E, de la Hoya M, Caldes T, Teule A, Lazaro C et al: Parity and the risk of breast and ovarian cancer in BRCA1 and BRCA2 mutation carriers. Breast Cancer Res Treat 2010, 119(1):221-232.

104. Medina D, Kittrell FS. p53 function is required for hormone-mediated protection of mouse mammary tumorigenesis. Cancer Res. 2003;63(19):6140-3.

105. Rajkumar L, Guzman RC, Yang J, Thordarson G, Talamantes F, Nandi S. Short-term exposure to pregnancy levels of estrogen prevents mammary carcinogenesis. ProcNat|AcadSciUSA. 2001;98(20):11755-9.

106. Rajkumar L, Kittrell FS, Guzman RC, Brown PH, Nandi S, Medina D. Hormoneinduced protection of mammary tumorigenesis in genetically engineered mouse models. Breast Cancer Res. 2007;9(1):R12.

107. Russo J, Ao X, Grill C, Russo IH. Pattern of distribution of cells positive for estrogen receptor alpha and progesterone receptor in relation to proliferating cells in the mammary gland. Breast Cancer ResTreat. 1999;53(3):217-27.

108. Russo J, Gusterson BA, Rogers AE, Russo IH, Wellings SR, van Zwieten MJ. Comparative study of human and rat mammary tumorigenesis. Lab Investig. 1990;62(3):244-78.

109. Dunphy KA, Blackburn AC, Yan H, O'Connell LR, Jerry DJ. Estrogen and progesterone induce persistent increases in p53-dependent apoptosis and suppress mammary tumors in BALB/C-Trp53+/- mice. Breast Cancer Res. 2008;10(3):R43.

110. Cohn BA, Terry MB, Plumb M, Cirillo PM. Exposure to polychlorinated biphenyl (PCB) congeners measured shortly after giving birth and subsequent risk of maternal breast cancer before age 50. Breast Cancer Res Treat. 2012;136(1):267-75.

111. Brody JG, Moysich KB, Humblet O, Attfield KR, Beehler GP, Rudel RA. Environmental pollutants and breast cancer: epidemiologic studies. Cancer. 2007;109(12 Suppl):2667-711

112. Rodgers KM, Udesky JO, Rudel RA, Brody JG. Environmental chemicals and breast cancer: an updated review of epidemiological literature informed by biological mechanisms. Environ Res. 2017;160:152-82.

113. Snedeker SM. Pesticides and breast cancer risk: a review of DDT, DDE, and dieldrin. Environ Health Perspect. 2001;109(Suppl 1):35-47.

114. Whyatt RM, Perzanowski MS, Just AC, Rundle AG, Donohue KM, Calafat AM, Hoepner LA, Perera FP, Miller RL. Asthma in inner-city children at 5-11 years of age and prenatal exposure to phthalates: the Columbia Center for Children's Environmental Health Cohort. Environ Health Perspect. 2014;122(10):1141-6.

115. Nie J, Beyea J, Bonner MR, Han D, Vena JE, Rogerson P, Vito D, Muti P, Trevisan M, Edge SB, et al. Exposure to traffic emissions throughout life and risk of breast cancer: the Western New York Exposures and Breast Cancer (WEB) study. Cancer Causes Control. 2007;18(9):947-55.

116. Mortensen ME, Calafat AM, Ye X, Wong LY, Wright DJ, Pirkle JL, Merrill LS, Moye J. Urinary concentrations of environmental phenols in pregnant women in a pilot study of the National Children's Study. Environ Res. 2014;129:32-8.

117. Philippat C, Wolff MS, Calafat AM, Ye X, Bausell R, Meadows M, Stone J, Slama R, Engel SM. Prenatal exposure to environmental phenols: concentrations in amniotic fluid and variability in urinary concentrations during pregnancy. Environ Health Perspect. 2013;121(10):1225-31.

118. Meier-Abt F, Milani E, Roloff T, Brinkhaus H, Duss S, Meyer DS, Klebba I, Balwierz PJ, van Nimwegen E, Bentires-Alj M. Parity induces differentiation and reduces Wnt/Notch signaling ratio and proliferation potential of basal stem/progenitor cells isolated from mouse mammary epithelium. Breast Cancer Res. 2013;15(2):R36.

119. Benz CC. Impact of aging on the biology of breast cancer. Crit Rev Oncol Hematol. 2008:66(1):65-74.

120. Pike MC, Spicer DV, Dahmoush L, Press MF. Estrogens, progestogens, normal breast cell proliferation, and breast cancer risk. Epidemiol Rev. 1993; 15(1):17-35.

121. Trichopoulos D, MacMahon B, Cole P. Menopause and breast cancer risk. J Natl Cancer Inst. 1972;48(3):605-13.

122. Cheng G, Li $Y$, Omoto $Y$, Wang $Y$, Berg $T$, Nord M, Vihko P, Warner $M$, Piao YS, Gustafsson JA. Differential regulation of estrogen receptor (ER) alpha and ERbeta in primate mammary gland. J Clin Endocrinol Metab. 2005;90(1):435-44. 
123. Khan SA, Rogers MA, Khurana KK, Meguid MM, Numann PJ. Estrogen receptor expression in benign breast epithelium and breast cancer risk. $J$ Natl Cancer Inst. 1998;90(1):37-42.

124. Rossouw JE, Anderson GL, Prentice RL, LaCroix AZ, Kooperberg C, Stefanick ML, Jackson RD, Beresford SA, Howard BV, Johnson KC, et al. Risks and benefits of estrogen plus progestin in healthy postmenopausal women: principal results. From the Women's Health Initiative randomized controlled trial. JAMA. 2002;288(3):321-33.

125. Chlebowski RT, Hendrix SL, Langer RD, Stefanick ML, Gass M, Lane D, Rodabough RJ, Gilligan MA, Cyr MG, Thomson CA, et al. Influence of estrogen plus progestin on breast cancer and mammography in healthy postmenopausal women: the Women's Health Initiative Randomized Trial. JAMA. 2003;289(24):3243-53.

126. Manson JE, Chlebowski RT, Stefanick ML, Aragaki AK, Rossouw JE, Prentice RL, Anderson G, Howard BV, Thomson CA, LaCroix AZ, et al. Menopausal hormone therapy and health outcomes during the intervention and extended poststopping phases of the Women's Health Initiative randomized trials. JAMA. 2013;310(13):1353-68.

127. Chlebowski RT, Rohan TE, Manson JE, Aragaki AK, Kaunitz A, Stefanick ML, Simon MS, Johnson KC, Wactawski-Wende J, O'Sullivan MJ, et al. Breast cancer after use of estrogen plus progestin and estrogen alone: analyses of data from 2 women's health initiative randomized clinical trials. JAMA Oncol. 2015; 1(3):296-305.

128. Byrne C, Ursin G, Martin CF, Peck JD, Cole EB, Zeng D, Kim E, Yaffe MD, Boyd NF, Heiss $G$ et al: Mammographic density change with estrogen and progestin therapy and breast cancer risk. J Natl Cancer Inst. 2017;109(9). https://doi.org/10.1093/jnci/djx001.

129. Santen RJ, Song Y, Yue W, Wang JP, Heitjan DF. Effects of menopausal hormonal therapy on occult breast tumors. J Steroid Biochem Mol Biol. 2013;137:150-6

130. Allen JG, McClean MD, Stapleton HM, Webster TF. Linking PBDEs in house dust to consumer products using X-ray fluorescence. Environ Sci Technol. 2008;42(11):4222-8.

131. Costa LG, Giordano G, Tagliaferri S, Caglieri A, Mutti A. Polybrominated diphenyl ether (PBDE) flame retardants: environmental contamination, human body burden and potential adverse health effects. Acta Biomed. 2008;79(3):172-83.

132. Darnerud PO. Brominated flame retardants as possible endocrine disrupters. Int J Androl. 2008;31(2):152-60.

133. Darnerud PO, Eriksen GS, Johannesson T, Larsen PB, Viluksela M. Polybrominated diphenyl ethers: occurrence, dietary exposure, and toxicology. Environ Health Perspect. 2001;109(Suppl 1):49-68.

134. Lorber M. Exposure of Americans to polybrominated diphenyl ethers. J Expo Sci Environ Epidemiol. 2008;18(1):2-19.

135. U.S. Department of Health and Human Services, Public Health Service: Toxicological Profile for Polybrominated Biphenyls and Polybrominated Diphenyl Ethers. In. Edited by U.S. Department of Health and Human Services Agency for Toxic Substances and Disease Registry. Atlanta; 2004.

136. He Y, Murphy MB, Yu RM, Lam MH, Hecker M, Giesy JP, Wu RS, Lam PK. Effects of 20 PBDE metabolites on steroidogenesis in the H295R cell line. Toxicol Lett. 2008;176(3):230-8.

137. Sprague BL, Trentham-Dietz A, Hedman CJ, Wang J, Hemming JD, Hampton JM, Buist DS, Aiello Bowles EJ, Sisney GS, Burnside ES. Circulating serum xenoestrogens and mammographic breast density. Breast Cancer Res. 2013; 15(3):R45.

138. Trabert B, Falk RT, Figueroa JD, Graubard BI, Garcia-Closas M, Lissowska J, Peplonska B, Fox SD, Brinton LA. Urinary bisphenol A-glucuronide and postmenopausal breast cancer in Poland. Cancer Causes Control. 2014;25(12): 1587-93.

139. Chen S, Zhou D, Hsin LY, Kanaya N, Wong C, Yip R, Sakamuru S, Xia M, Yuan YC, Witt $K$, et al. AroER tri-screen is a biologically relevant assay for endocrine disrupting chemicals modulating the activity of aromatase and/ or the estrogen receptor. Toxicol Sci. 2014;139(1):198-209.

140. Sprague BL, Trentham-Dietz A, Hedman CJ, Wang J, Hemming JD, Hampton JM, Buist DS, Bowles EJ, Burnside ES. Authors' response. Breast Cancer Res. 2013;15(5):403

141. Holtcamp W. Obesogens: an environmental link to obesity. Environ Health Perspect. 2012;120(2):a62-8.

142. Byrne C, Divekar SD, Storchan GB, Parodi DA, Martin MB. Cadmium--a metallohormone? Toxicol Appl Pharmacol. 2009;238(3):266-71.
143. Byrne C, Divekar SD, Storchan GB, Parodi DA, Martin MB. Metals and breast cancer. J Mammary Gland Biol Neoplasia. 2013;18(1):63-73.

144. Garcia-Morales P, Saceda M, Kenney N, Kim N, Salomon DS, Gottardis MM, Solomon HB, Sholler PF, Jordan VC, Martin MB. Effect of cadmium on estrogen receptor levels and estrogen-induced responses in human breast cancer cells. J Biol Chem. 1994;269(24):16896-901.

145. Choe SY, Kim SJ, Kim HG, Lee JH, Choi Y, Lee H, Kim Y. Evaluation of estrogenicity of major heavy metals. Sci Total Environ. 2003;312(1-3):15-21.

146. Martinez-Campa C, Alonso-Gonzalez C, Mediavilla MD, Cos S, Gonzalez A, Ramos S, Sanchez-Barcelo EJ. Melatonin inhibits both ER alpha activation and breast cancer cell proliferation induced by a metalloestrogen, cadmium. J Pineal Res. 2006;40(4):291-6.

147. Siewit CL, Gengler B, Vegas E, Puckett R, Louie MC. Cadmium promotes breast cancer cell proliferation by potentiating the interaction between ERalpha and c-Jun. Mol Endocrinol. 2010;24(5):981-92.

148. Brama M, Gnessi L, Basciani S, Cerulli N, Politi L, Spera G, Mariani S, Cherubini S, Scotto d'Abusco A, Scandurra R, et al. Cadmium induces mitogenic signaling in breast cancer cell by an ERalpha-dependent mechanism. Mol Cell Endocrinol. 2007;264(1-2):102-8.

149. Stoica A, Katzenellenbogen BS, Martin MB. Activation of estrogen receptoralpha by the heavy metal cadmium. Mol Endocrinol. 2000;14(4):545-53.

150. Wilson VS, Bobseine K, Gray LE Jr. Development and characterization of a cell line that stably expresses an estrogen-responsive luciferase reporter for the detection of estrogen receptor agonist and antagonists. Toxicol Sci. 2004;81(1):69-77.

151. Liu Z, Yu X, Shaikh ZA. Rapid activation of ERK1/2 and AKT in human breast cancer cells by cadmium. Toxicol Appl Pharmacol. 2008;228(3):286-94.

152. Zang Y, Odwin-Dacosta S, Yager JD. Effects of cadmium on estrogen receptor mediated signaling and estrogen induced DNA synthesis in T47D human breast cancer cells. Toxicol Lett. 2009;184(2):134-8.

153. Adams SV, Newcomb PA, White E. Dietary cadmium and risk of invasive postmenopausal breast cancer in the VITAL cohort. Cancer Causes Control. 2012;23(6):845-54

154. Adams SV, Quraishi SM, Shafer MM, Passarelli MN, Freney EP, Chlebowski RT, Luo J, Meliker JR, Mu L, Neuhouser ML, et al. Dietary cadmium exposure and risk of breast, endometrial, and ovarian cancer in the Women's Health Initiative. Environ Health Perspect. 2014;122(6):594-600.

155. Eriksen KT, Halkjaer J, Sorensen M, Meliker JR, McElroy JA, Tjonneland A, Raaschou-Nielsen O. Dietary cadmium intake and risk of breast, endometrial and ovarian cancer in Danish postmenopausal women: a prospective cohort study. PLoS One. 2014;9(6):e100815.

156. Grioni S, Agnoli C, Krogh V, Pala V, Rinaldi S, Vinceti M, Contiero P, Vescovi L, Malavolti M, Sieri S. Dietary cadmium and risk of breast cancer subtypes defined by hormone receptor status: a prospective cohort study. Int J Cancer. 2019;144(9):2153-60.

157. Itoh H, Iwasaki M, Sawada N, Takachi R, Kasuga Y, Yokoyama S, Onuma $H$, Nishimura $H$, Kusama R, Yokoyama K, et al. Dietary cadmium intake and breast cancer risk in Japanese women: a case-control study. Int J Hyg Environ Health. 2014;217(1):70-7.

158. Julin B, Wolk A, Bergkvist L, Bottai M, Akesson A. Dietary cadmium exposure and risk of postmenopausal breast cancer: a population-based prospective cohort study. Cancer Res. 2012;72(6):1459-66.

159. Sawada N, Iwasaki M, Inoue M, Takachi R, Sasazuki S, Yamaji T, Shimazu T, Endo $Y$, Tsugane S. Long-term dietary cadmium intake and cancer incidence. Epidemiology. 2012;23(3):368-76.

160. Amadou A, Praud D, Coudon T, Danjou AMN, Faure E, Leffondre K, Le Romancer M, Severi G, Salizzoni P, Mancini FR, et al. Chronic long-term exposure to cadmium air pollution and breast cancer risk in the French E3N cohort. Int J Cancer. 2019. https://doi.org/10.1002/ijc.32257.

161. White A, O'Brien KM, Niehoff NM, Carroll R, Sandler DP. Metallic air pollutants and breast cancer risk in a nationwide cohort study. Epidemiology. 2019;30(1):20-8.

162. Adams SV, Shafer MM, Bonner MR, LaCroix AZ, Manson JE, Meliker JR, Neuhouser ML, Newcomb PA. Urinary cadmium and risk of invasive breast cancer in the women's health initiative. Am J Epidemiol. 2016; 183(9):815-23.

163. Gaudet MM, Deubler EL, Kelly RS, Ryan Diver W, Teras LR, Hodge JM, Levine KE, Haines $L G$, Lundh $T$, Lenner $P$, et al. Blood levels of cadmium and lead in relation to breast cancer risk in three prospective cohorts. Int J Cancer. 2018;144:1010-6.

164. Nagata C, Nagao Y, Nakamura K, Wada K, Tamai Y, Tsuji M, Yamamoto S, Kashiki Y. Cadmium exposure and the risk of breast cancer in Japanese women. Breast Cancer Res Treat. 2013;138(1):235-9. 
165. McElroy JA, Shafer MM, Trentham-Dietz A, Hampton JM, Newcomb PA. Cadmium exposure and breast cancer risk. J Natl Cancer Inst. 2006;98(12):869-73.

166. Gallagher CM, Chen JJ, Kovach JS. Environmental cadmium and breast cancer risk. Aging (Albany NY). 2010;2(11):804-14.

167. O'Brien KM, White AJ, Jackson BP, Karagas MR, Sandler DP, Weinberg CR. Toenail-based metal concentrations and young-onset breast cancer. Am J Epidemiol. 2019;188(4):646-55.

168. White AJ, Weinberg CR, O'Meara ES, Sandler DP, Sprague BL. Airborne metals and polycyclic aromatic hydrocarbons in relation to mammographic breast density. Breast Cancer Res. 2019;21(1):24.

169. Adams SV, Hampton JM, Trentham-Dietz A, Gangnon RE, Shafer MM, Newcomb PA. Urinary cadmium and mammographic density. Epidemiology. 2017;28(1):e6-7.

170. Adams SV, Newcomb PA, Shafer MM, Atkinson C, Bowles EJ, Newton KM, Lampe JW. Urinary cadmium and mammographic density in premenopausal women. Breast Cancer Res Treat. 2011;128(3):837-44.

171. Mora-Pinzon MC, Trentham-Dietz A, Gangnon RE, Adams SV, Hampton JM, Burnside E, Shafer MM, Newcomb PA. Urinary magnesium and other elements in relation to mammographic Breast density, a measure of breast cancer risk. Nutr Cancer. 2018;70(3):441-6.

172. Marshall WA, Tanner JM. Variations in pattern of pubertal changes in girls. Arch Dis Child. 1969:44(235):291-303.

173. Biro FM, Pinney SM, Schwartz RC, Huang B, Cattran AM, Haslam SZ. Amphiregulin as a novel serum marker of puberty in girls. J Pediatr Adolesc Gynecol. 2017;30(5):535-9.

174. Knight JA, Blackmore KM, Wong J, Tharmalingam S, Lilge L. Optical spectroscopy of the breast in premenopausal women reveals tissue variation with changes in age and parity. Med Phys. 2010;37(2):419-26.

175. Blackmore KM, Knight JA, Walter J, Lilge L. The association between breast tissue optical content and mammographic density in pre- and postmenopausal women. PLoS One. 2015;10(1):e0115851.

176. Walter EJ, Knight JA, Lilge L. A multi-wavelength, laser-based optical spectroscopy device for breast density and breast cancer risk pre-screening. J Biophotonics. 2017;10(4):565-76.

177. Blyschak K, Simick M, Jong R, Lilge L. Classification of breast tissue density by optical transillumination spectroscopy: optical and physiological effects governing predictive value. Med Phys. 2004;31(6):1398-414.

178. Blackmore KM, Knight JA, Lilge L. Association between transillumination breast spectroscopy and quantitative mammographic features of the breast. Cancer Epidemiol Biomarkers Prev. 2008;17(5):1043-50.

179. Walter EJ, Lilge L. Optical assessment of mammographic breast density by a 12-wavelength vs a continuous-spectrum optical spectroscopy device. J Biophotonics. 2018;11(2). https://doi.org/10.1002/jbio.201700071.

180. Byrne C, Schairer C, Wolfe J, Parekh N, Salane M, Brinton LA, Hoover R, Haile R. Mammographic features and breast cancer risk: effects with time, age, and menopause status. J Natl Cancer Inst. 1995;87(21):1622-9.

181. Sak MA, Littrup PJ, Duric N, Mullooly M, Sherman ME, Gierach GL. Current and future methods for measuring breast density: a brief comparative review. Breast Cancer Manag. 2015;4(4):209-21.

182. McCormack VA, dos Santos SI. Breast density and parenchymal patterns as markers of breast cancer risk: a meta-analysis. Cancer Epidemiol Biomark Prev. 2006;15(6):1159-69.

183. Maskarinec G, Pagano I, Lurie G, Kolonel LN. A longitudinal investigation of mammographic density: the multiethnic cohort. Cancer Epidemiol Biomark Prev. 2006;15(4):732-9.

184. Boyd N, Martin L, Stone J, Little L, Minkin S, Yaffe M. A longitudinal study of the effects of menopause on mammographic features. Cancer Epidemiol Biomarkers Prev. 2002:11(10 Pt 1):1048-53.

185. Lokate M, Stellato RK, Veldhuis WB, Peeters PH, van Gils CH. Age-related changes in mammographic density and breast cancer risk. Am J Epidemiol. 2013;178(1):101-9.

186. Work ME, Reimers LL, Quante AS, Crew KD, Whiffen A, Terry MB. Changes in mammographic density over time in breast cancer cases and women at high risk for breast cancer. Int J Cancer. 2014;135(7):1740-4.

187. Kerlikowske K, Ichikawa L, Miglioretti DL, Buist DS, Vacek PM, SmithBindman R, Yankaskas B, Carney PA, Ballard-Barbash R. National Institutes of Health Breast Cancer Surveillance Consortium: longitudinal measurement of clinical mammographic breast density to improve estimation of breast cancer risk. J Natl Cancer Inst. 2007; 99(5):386-95.

188. Boyd N, Martin L, Chavez S, Gunasekara A, Salleh A, Melnichouk O, Yaffe M, Friedenreich C, Minkin S, Bronskill M. Breast-tissue composition and other risk factors for breast cancer in young women: a cross-sectional study. Lancet Oncol. 2009;10(6):569-80.

189. Bertrand KA, Baer HJ, Orav EJ, Klifa C, Shepherd JA, Van Horn L, Snetselaar L, Stevens VJ, Hylton NM, Dorgan JF. Body fatness during childhood and adolescence and breast density in young women: a prospective analysis. Breast Cancer Res. 2015;17:95.

190. Denholm R, De Stavola B, Hipwell JH, Doran SJ, Busana MC, Eng A, Jeffreys M, Leach MO, Hawkes D, Dos Santos SI. Pre-natal exposures and breast tissue composition: findings from a British pre-birth cohort of young women and a systematic review. Breast Cancer Res. 2016;18(1):102.

191. Novotny R, Daida Y, Morimoto Y, Shepherd J, Maskarinec G. Puberty, body fat, and breast density in girls of several ethnic groups. Am J Hum Biol. 2011;23(3):359-65.

192. Gaskins AJ, Pereira A, Quintiliano D, Shepherd JA, Uauy R, Corvalan C, Michels KB. Dairy intake in relation to breast and pubertal development in Chilean girls. Am J Clin Nutr. 2017;105(5):1166-75.

193. Lyons TR, O'Brien J, Borges VF, Conklin MW, Keely PJ, Eliceiri KW, Marusyk A, Tan AC, Schedin P. Postpartum mammary gland involution drives progression of ductal carcinoma in situ through collagen and COX-2. Nat Med. 2011;17(9):1109-15.

194. Provenzano PP, Inman DR, Eliceiri KW, Knittel JG, Yan L, Rueden CT, White JG, Keely PJ. Collagen density promotes mammary tumor initiation and progression. BMC Med. 2008;6:11

195. Brown JQ, Wilke LG, Geradts J, Kennedy SA, Palmer GM, Ramanujam N. Quantitative optical spectroscopy: a robust tool for direct measurement of breast cancer vascular oxygenation and total hemoglobin content in vivo. Cancer Res. 2009;69(7):2919-26.

196. Lilge L, Terry MB, Walter J, Pinnaduwage D, Glendon G, Hanna D, Tammemagi M, Bradbury AR, Buys SS, Daly MB, et al. Non-invasive optical spectroscopic (OS) monitoring of breast development during puberty. Breast Cancer Res. 2017;19(1):12.

197. Brody JG, Dunagan SC, Morello-Frosch R, Brown P, Patton S, Rudel RA. Reporting individual results for biomonitoring and environmental exposures: lessons learned from environmental communication case studies. Environ Health. 2014;13:40.

198. Hernick AD, Brown MK, Pinney SM, Biro FM, Ball KM, Bornschein RL. Sharing unexpected biomarker results with study participants. Environ Health Perspect. 2011;119(1):1-5.

199. Boronow KE, Susmann HP, Gajos KZ, Rudel RA, Arnold KC, Brown P, MorelloFrosch R, Havas L, Brody JG. DERBI: a digital method to help researchers offer "right-to-know" personal exposure results. Environ Health Perspect. 2017;125(2):A27-33.

200. Silk K, Perrault EK, Neuberger L, Rogers A, Atkin C, Barlow J, Duncan DM. Translating and testing breast cancer risk reduction messages for mothers of adolescent girls. J Health Commun. 2014;19(2):226-43.

201. Balazs CL, Morello-Frosch R: The three R's: how community based participatory research strengthens the rigor, relevance and reach of science. Environ Justice. 2013;6(1). https://doi.org/10.1089/env.2012.0017.

202. Howlader N, Noone AM, Krapcho M, Miller D, Bishop K, Kosary CL, Yu M, Ruhl J, Tatalovich Z, Mariotto A et al: SEER Cancer Statistics Review, 19752014. In.; National Cancer Institute. Bethesda, MD, https://seer.cancer.gov/ csr/1975_2014/, based on November 2016 SEER data submission, posted to the SEER web site, April 2017.

203. ACOG. Committee Opinion No 575: Exposure to toxic environmental agents. Obstet Gynecol. 2013;122(4):931-5.

204. Attina TM, Malits J, Naidu M, Trasande L. Racial/ethnic disparities in disease burden and costs related to exposure to endocrine-disrupting chemicals in the United States: an exploratory analysis. J Clin Epidemiol. 2019;108:34-43.

205. James W, Jia C, Kedia S. Uneven magnitude of disparities in cancer risks from air toxics. Int J Environ Res Public Health. 2012;9(12):4365-85.

206. 2018-2023 Strategic Plan: Advancing Environmental Health Sciences, Improving Health. In.; NIH Publication No. 18-ES-7935. National Institute of Environmental Health Sciences, National Institutes of Health, US Department of Health and Human Services; 2018. (www.niehs.nih.gov) (Accessed 1 Oct 2018).

207. Terry MB, Forman MR. Empowering pediatricians to prevent chronic disease across generations. Pediatrics. 2016;138(Suppl 1):S92-4.

\section{Publisher's Note}

Springer Nature remains neutral with regard to jurisdictional claims in published maps and institutional affiliations. 